\title{
Determination of Optimum Operating Conditions of Different Types of Intercooler Designs in Supercharged Engines
}

\author{
Cengiz Öner ${ }^{1}$ and Ali Öz ${ }^{2 *}$ \\ 0000-0002-3278-2831 ${ }^{1}, 0000-0002-0814-4020^{2 *}$
}

${ }^{1}$ Bingöl University, Faculty of Engineering and Architecture, Mechanical Engineering Department, Bingöl, Türkiye

${ }^{2 *}$ Mehmet Akif Ersoy University, Vocational School of Technical Sciences, Department of Motor Vehicles and Transport Technologies, Burdur, Turkey

\begin{abstract}
In the rapidly developing automotive technology, the efforts to achieve high performance with less fuel consumption is one of the most important issues today. The purpose of the supercharged systems developed for this reason is to send more air into the cylinder. For high engine performance and low exhaust emission values, the intake air temperature, which is heated in the turbo-compressor and has the oxygen concentration (the amount of oxygen in the unit air) decreased, must be kept at certain levels. Therefore, the heated air between the compressor outlet and the cylinder inlet must be cooled. In this study, different types of intercoolers were designed and analyzed with the help of ANSYS Fluent (CFD) program, and optimum conditions were tried to be obtained by comparing them with each other.
\end{abstract}

Keywords: Intercooler, Turbocharger, CFD analysis, Optimization

\section{Research Article}

https://doi.org/10.30939/ijastech..1013286

$\begin{array}{ll}\text { Received } & 21.10 .2021 \\ \text { Revised } & 07.12 .2021 \\ \text { Accepted } & 08.12 .2021\end{array}$

* Corresponding author

Ali Öz

alioz@mehmetakif.edu.tr

Address: Mehmet Akif Ersoy University, Vocational School of Technical Sciences, Department of Motor Vehicles and Transport Technologies, Burdur, Turkey

\section{Introduction}

The temperature and flow rate of exhaust gases of internal combustion engines can be converted into useful energy for the engine by using heat exchangers with different geometric structures and properties. In the literature, there are many studies in which the kinetic and heat energy of the exhaust gases are converted into useful energy for the engine [1-3]. Supercharging applications in internal combustion piston engines are an important improvement for the user, the manufacturer and the environmental conditions. Today, there are many studies on supercharging to improve power and fuel economy in diesel and gasoline engines used in vehicles [4-6]. Supercharging in brief, means filling the cylinders of internal combustion piston engines at pressures higher than atmospheric pressure and therefore at higher density with a compressor. In supercharged engines, the density of the air sucked into the engine and the amount of sucked air decrease due to the increase in temperature, and as a result the engine power decreases. To avoid this, the charge air must be cooled before it is sent to the engine. The average effective pressure increases thanks to the supercharging done by cooling the charge air; higher power, increase in engine efficiency and decrease in specific fuel consumption are provided from engines with small cylinder volumes. However, the improvement of in-cylinder combustion conditions in supercharged engines causes serious decreases in $\mathrm{HC}$ and $\mathrm{CO}$ emissions, which are incomplete and bad combustion products, and a slight increase in NOx emissions [7, 8]. One of the most important and most encountered processes in engineering application areas is the process of providing heat transfer between two or more fluids at different temperatures. The devices used in this transfer are called heat exchangers or exchangers, and those used in turbocharged engines are specified as intercoolers [9, 10]. In heat exchangers, the fluids are separated from each other by a solid surface, mostly a metal material where the heat transfer is done directly without mixing with each other. Heat exchangers can be classified in various ways according to the type of heat transfer, structure properties, flow regulation, number of fluids or phase changes of fluids [11-13]. The maximum power an internal combustion engine can deliver is limited by the amount of fuel it can burn efficiently in its cylinders. And this is related to the air consumption that is taken into the cylinder in one cycle and that will enable the fuel to burn. In order to get more power from an engine of the same volume, it is necessary to take more air into the cylinder. This happens with the application of supercharging [14-16]. In turbocharging, the compressor part is driven by the turbine, which is converted by the energy of the exhaust gas 
exiting the engine's exhaust manifold [17-20]. With the increase in the pressure of the air sent from the turbine to the cylinders, the temperature rises, and the air density decreases, and the mass flow of the air sent to the cylinders decreases. The air is cooled by passing it through a heat exchanger to increase the mass airflow [19,20]. Turbo charging system and intercooler system are shown in Figure 1.

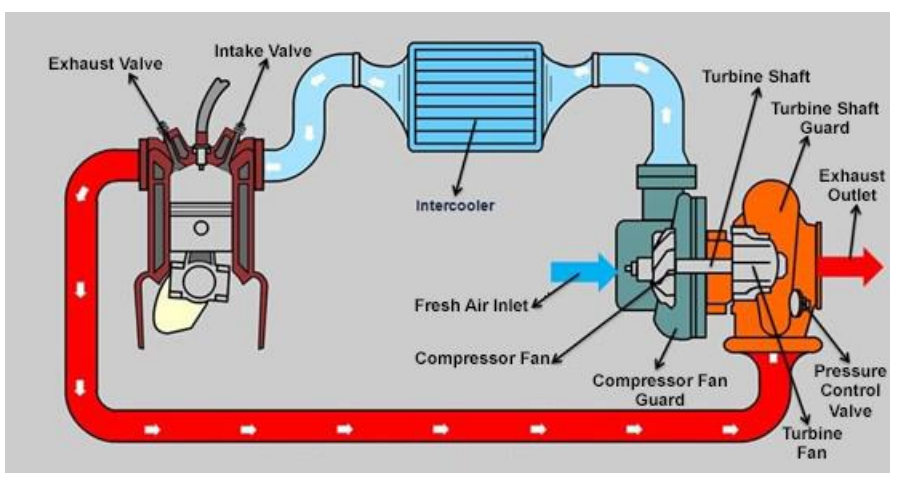

Fig 1. Turbocharger and intercooler system [15]

In this study, two different types of shell and tube heat exchangers were selected, and CFD analyzes were carried out to determine the heat transfer performance of the intercooler with the same fluid and different speeds.

Qinguo Zhang et al. designed a fin-tube intercooler and investigated the temperature and pressure distribution numerically with the help of the software named FLUENT. In their study, they analyzed the effects of air flow rate on the heat transfer performance and resistance characteristics of the intercooler they designed. They stated that the heat transfer capacity and pressure drop increased by increasing the air flow rate of the designed intercooler, and the flow rate had a significant effect on the heat exchange efficiency [21]. Vishwa Deepak Dwivedi et al. aimed high efficiency and minimum fuel consumption in automobiles in their study. To achieve this, they used "Nano fluid" to increase the heat transfer performance in automobile radiator. The wavy fin type radiator was modeled with CATIA V5 software and the performance evaluation was made with the preprocessing software ANSYS 14.0. Calculation of refrigerant velocity and air temperature distribution was analyzed using fluid dynamics, environmental software CFX. The use of nanofluid ( $\mathrm{Si} \mathrm{C}+$ water) has shown that heat transfer is better than the use of conventional refrigerant [22]. Piotr Wais F., who examined the effect of fin thickness and fin orientation on mass and heat transfer in a crossflow heat exchanger, analyzed the heat transfer at different fin thicknesses by simulation and investigated the effects on heat transfer efficiency and pressure drop by adding different fins in the experimental study [23]. M.Y.A Mifdal et al. designed a cooling system with a turbo intercooler. With the help of temperature sensors placed on the intercooler, this system activates when the temperature in the intercooler exceeds $36^{\circ} \mathrm{C}$ and aims to reduce the temperature of the intercooler by pumping water into the system. They tried to get results from their experimental studies by reading the real temperature values on the microcontroller and LCD screen [24]. Naser B. Lajgi et al. investigated the effect of different intercoolers on the performance of a turbocharged diesel engine. In their study, they examined the performance of the intercooler in three different dimensions and depending on the total heat transfer coefficient in multi-cylinder engine performance at $1600 \mathrm{rpm}$ constant engine speed operating condition with the codes they programmed in MATLAB. They evaluated the temperature and pressure drop in the cylinders for three different intercoolers. In their study, they stated that engine power and volumetric efficiency increased under some conditions, and they also stated that the performance of the intercooler they simulated increased [25].

\section{Materials and Method}

\subsection{Physical Model}

The main purpose of the study is to improve combustion performance by reducing the intake air inlet temperature in turbocharger systems. For these purposes, two different types of intercoolers have been designed for cooling at the turbo compressor outlet. Circular and ellipsoidal air flow channels have been placed inside the body of the same dimensions. Circular channels consist of two vertical rows as seen in Figure 2 and Figure 3, and ellipsoidal channels consist of two horizontal-vertical rows as seen in Figure 4 and Figure 5 .

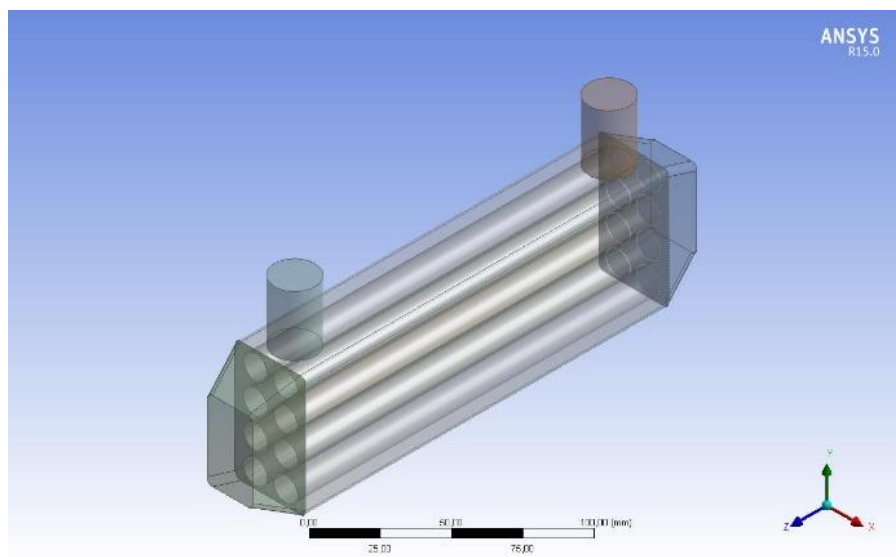

Fig. 2. Circular tubular geometry

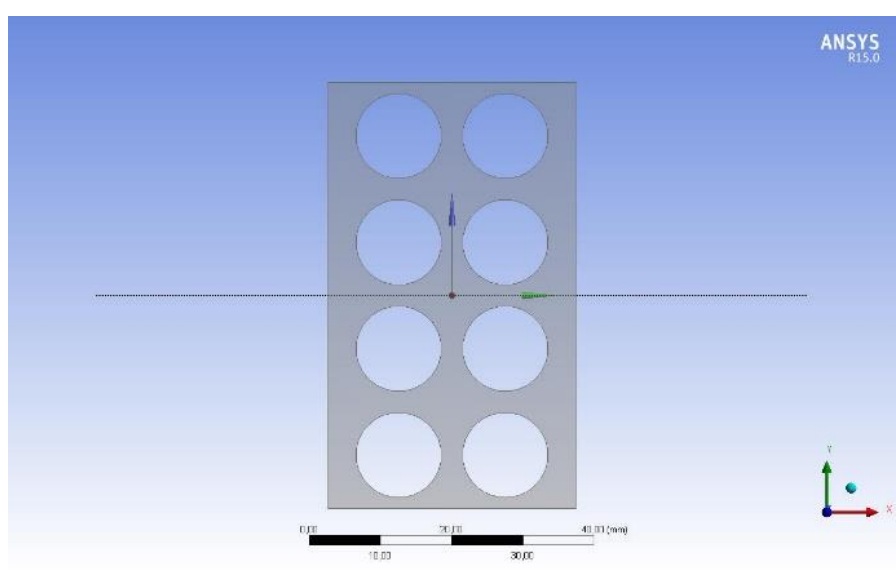

Fig. 3. Circular section front view 
As shown in Table 1, the body section, body length, inlet section and number of tubes were taken as the same in the geometries used; In order to increase the efficiency of the flow turbulence by considering the minimum difference in surface area compared to the tube channel structures, the tube layouts are foreseen as straight rows in the circular structure and horizontal-vertical in the ellipsoid structure. While determining these values, the main dimensions of the intercooler on the Toyota 2.0 engine and the one used in the literature were taken as reference.

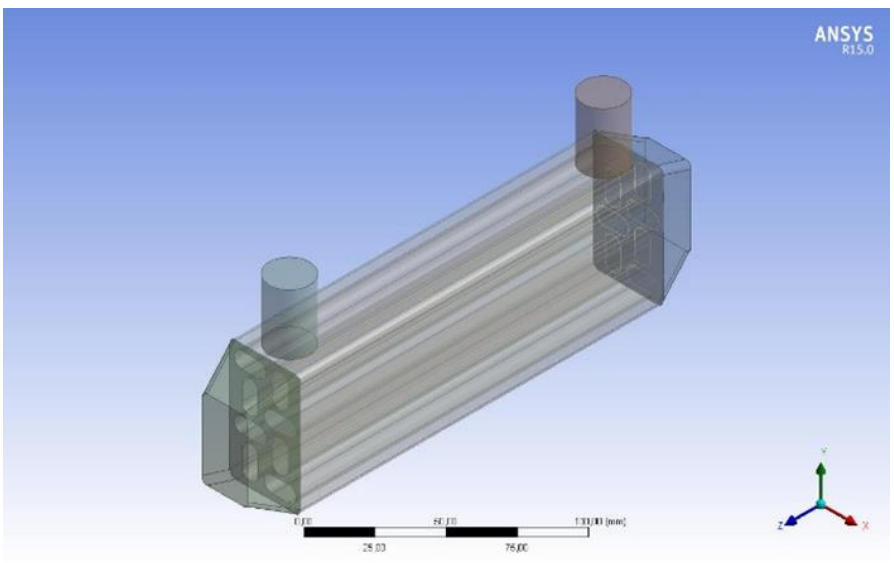

Fig. 4. Ellipsoid tubular geometry

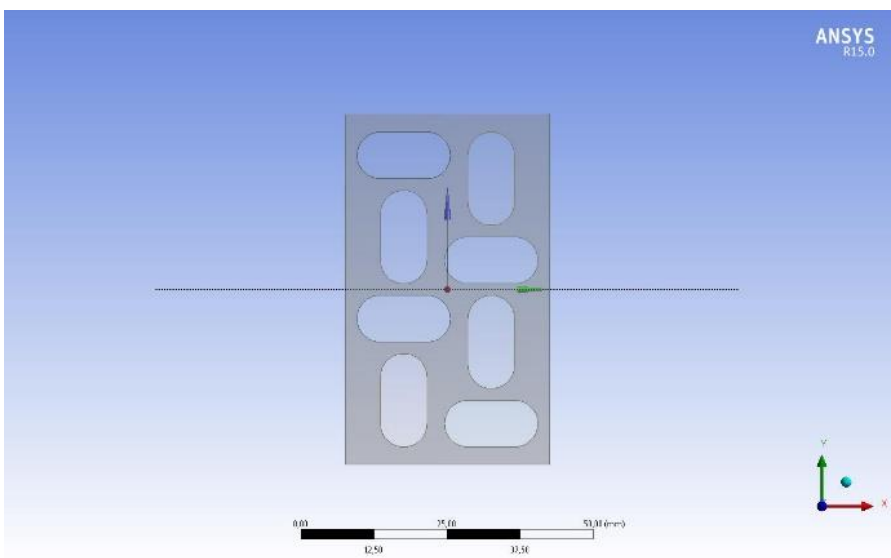

Fig. 5. Ellipsoid section front view

Table 1. Intercooler geometry parameters

\begin{tabular}{|c|c|c|}
\hline & $\begin{array}{c}\text { Circular section } \\
\text { tube }\end{array}$ & $\begin{array}{c}\text { Ellipsoid section } \\
\text { tube }\end{array}$ \\
\hline Body section & \multicolumn{2}{|c|}{$35 \times 60$} \\
\hline Body length & \multicolumn{2}{|c|}{$23 \times \mathrm{mm}$} \\
\hline Input section & \multicolumn{2}{|c|}{89,4} \\
\hline Number of tubes & $54208 \mathrm{~mm}^{2}$ & $59040 \mathrm{~mm}^{2}$ \\
\hline $\begin{array}{c}\text { Total tube surface } \\
\text { area }\end{array}$ & Straight row & $\begin{array}{c}\text { Horizontal - Vertic } \\
\text { al row }\end{array}$ \\
\hline Tube layout &
\end{tabular}

\subsection{Basic Mathematical Equations}

For intercoolers working as heat exchangers, calculations can be made with the calculation methods used for heat exchangers. The heat transfer in air and water is equal, and the resulting heat transfer is obtained by the equation (2.1):

$$
Q=U x A x \Delta T_{l m}
$$

Average logarithmic temperature difference used when calculating heat transfer is calculated from the equation (2.2).

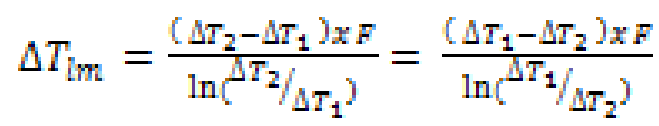

The mean logarithmic temperature difference of the Parallel Flow heat exchangers used in the study can be found with the equations (2.3) and (2.4).

$$
\begin{aligned}
& \Delta T_{1}=T_{h_{i} \mathrm{i}}-T_{\mathrm{CQ}_{\mathrm{i}}} \\
& \Delta T_{2}=T_{\mathrm{h}_{\mathrm{i}} \mathrm{O}}-T_{\mathrm{c}_{\mathrm{O}} \mathrm{O}}
\end{aligned}
$$

Conservation of energy:

$$
\rho\left(\frac{\partial e}{\partial t}+u_{x} \frac{\partial e}{\partial x}+v \cdot \frac{\partial e}{\partial y}+w \cdot \frac{\partial e}{\partial z}\right)=
$$

$$
\begin{aligned}
& \left(\frac{\partial}{\partial x}\left(\lambda \cdot \frac{\partial \tau}{\partial x}\right)+\frac{\partial}{\partial y}\left(\lambda \cdot \frac{\partial \tau}{\partial y}\right)+\frac{\partial}{\partial z}\left(\lambda \cdot \frac{\partial \tau}{\partial z}\right)\right) \\
& -p_{v}(\nabla \cdot v)+k \cdot v+\rho \cdot q_{s}+\mu \cdot \phi
\end{aligned}
$$

$$
\begin{aligned}
& \Phi=2 \cdot\left[\left(\frac{\partial u}{\partial x}\right)^{2}+\left(\frac{\partial v}{\partial y}\right)^{2}+\left(\frac{\partial w}{\partial z}\right)^{2}\right]+\left(\frac{\partial v}{\partial x}+\frac{\partial u}{\partial y}\right)^{2} \\
& +\left(\frac{\partial w}{\partial y}+\frac{\partial v}{\partial z}\right)^{2}+\left(\frac{\partial u}{\partial z}+\frac{\partial w}{\partial x}\right)^{2}-\frac{2}{3} \cdot\left(\frac{\partial u}{\partial x}+\frac{\partial v}{\partial y}+\frac{\partial w}{\partial z}\right)^{2}
\end{aligned}
$$

\subsection{Boundary Conditions}

Based on the above-mentioned heat transfer basic equations for the geometries to be simulated: Constant temperature and constant air velocity were accepted as input boundary conditions as indicated in Table 2, then variable speeds were defined (different Re numbers) and the results were examined. The outlet boundary condition was defined as pressure. Body surfaces were assumed to be adiabatic at constant temperature. Aluminum with pipe material density of $2700 \mathrm{~kg} / \mathrm{m} 3$, thermal conductivity of $\mathrm{k}=220 \mathrm{~W} / \mathrm{mK}$ and specific heat value of $\mathrm{Cp}=870 \mathrm{j} / \mathrm{kgK}$ was used. 
Table 2. Fluid parameters

\begin{tabular}{c|c}
\hline Air Inlet Temperature & $373 \mathrm{~K}$ \\
\hline Air Inlet Rate & $21-25 \mathrm{~m} / \mathrm{s}$ \\
\hline Refrigerant Inlet Temperature & $298 \mathrm{~K}$ \\
\hline Refrigerant Inlet Rate & $1-2 \mathrm{~m} / \mathrm{s}$ \\
\hline
\end{tabular}

\section{Findings and Discussion}

Recent numerical studies focus on optimum design processes in order to increase the heat transfer performance. In this way, different geometries with the same dimensions are developed and the most suitable one is determined. In the study, different air flow channels were designed and numerical analyzes were carried out for the intercooler with the same dimensions. The geometry was created in ANSYS Workbench; Mesh independence was achieved by evaluating four different grid structures with 450000,500000 , 550000 and 650000 element numbers according to the air outlet temperature. Around 500000 mesh structures were considered appropriate. K-epsilon, realizable, turbulence models were used in the analysis. Water at a temperature of $298 \mathrm{~K}$ was used as the refrigerant. The temperature changes of the intercooler designed with circular channel geometry is given in Figure 6, Figure 7 and Figure 8.

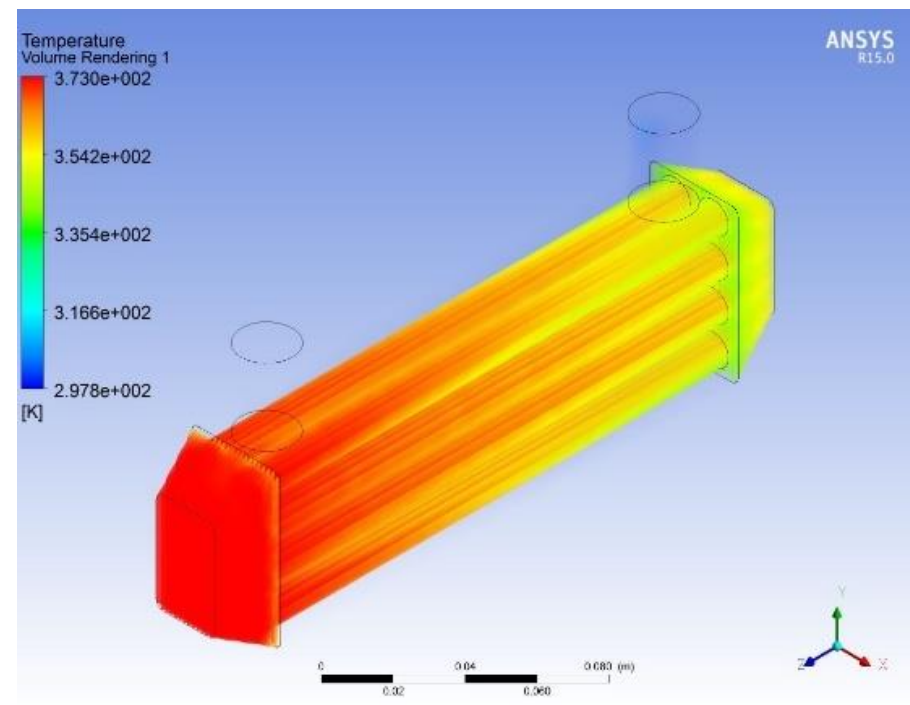

Fig. 6. Circular channel temperature variation

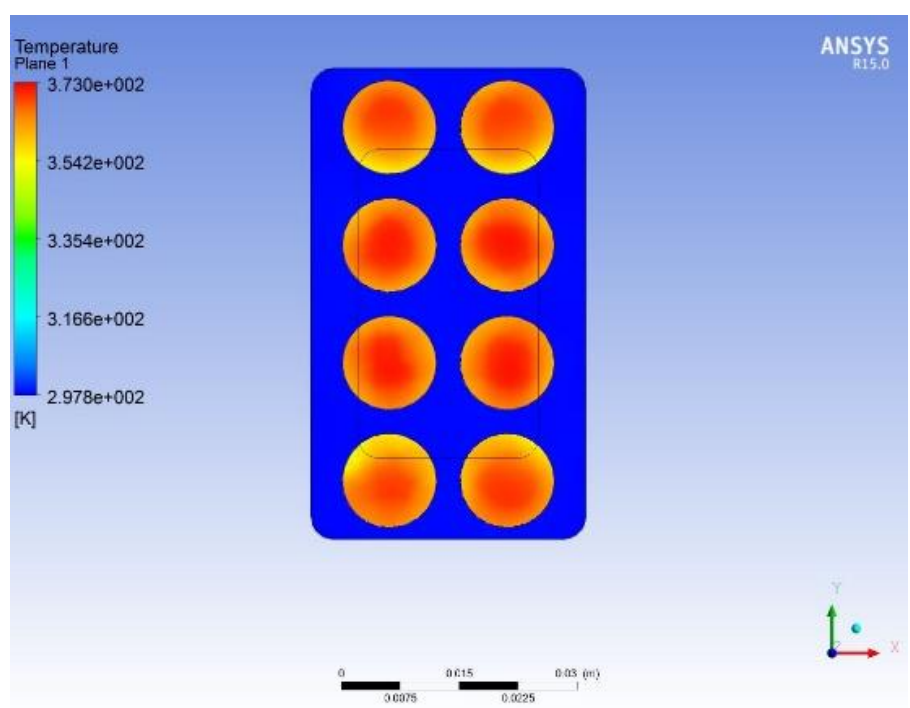

Fig. 7. Circular $\mathrm{X}=0,06 \mathrm{~m}$ section view

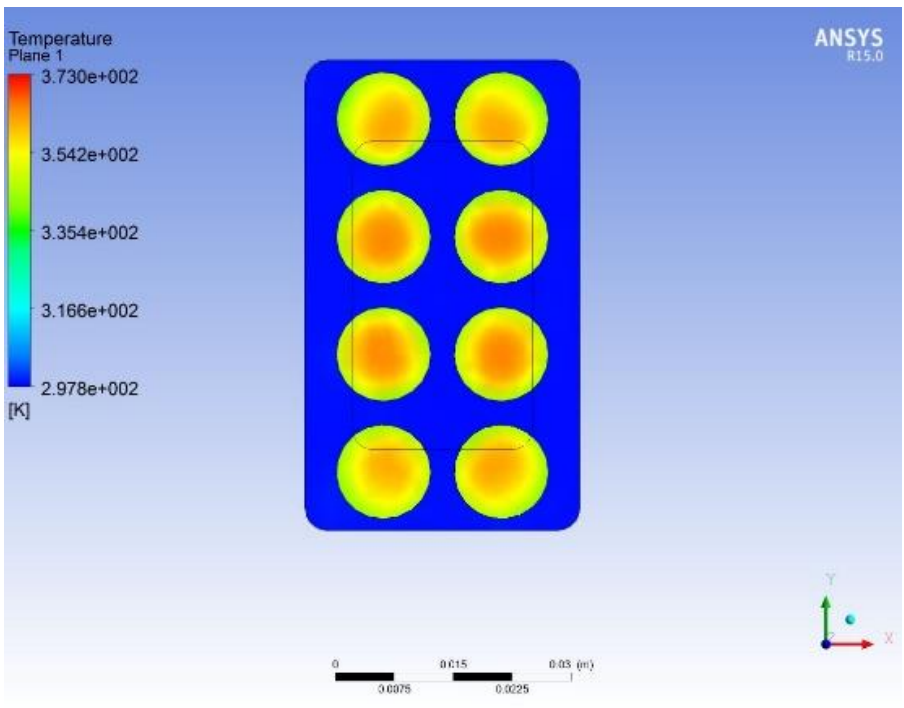

Fig 8. Circular $\mathrm{X}=0,12 \mathrm{~m}$ section view

In the analysis, the effects of boundary conditions and geometries on heat transfer were investigated. The intercooler examined in the study was investigated by changing the velocities of air and water, and how the geometries affect each other and the boundary conditions. The analysis results and numerical values shown in Figure 9, Figure 10 and Figure 11 demonstrate that the use of ellipsoidal air ducts is more effective in heat transfer. The high temperature air entering the intercooler was tried to be cooled in both geometries designed with water as the refrigerant. 


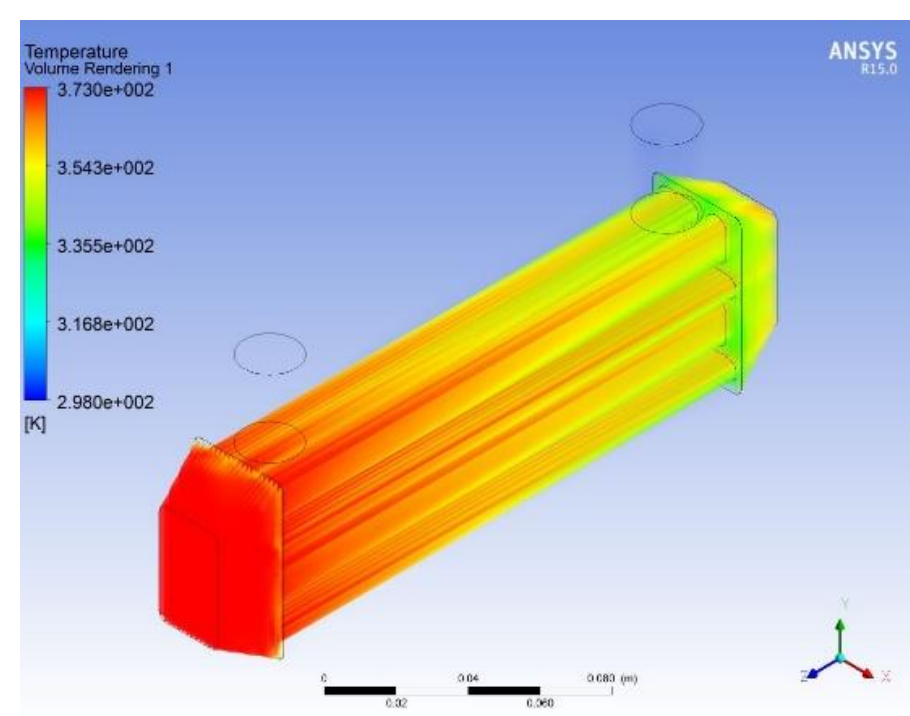

Fig. 9. Ellipsoid channel temperature variation

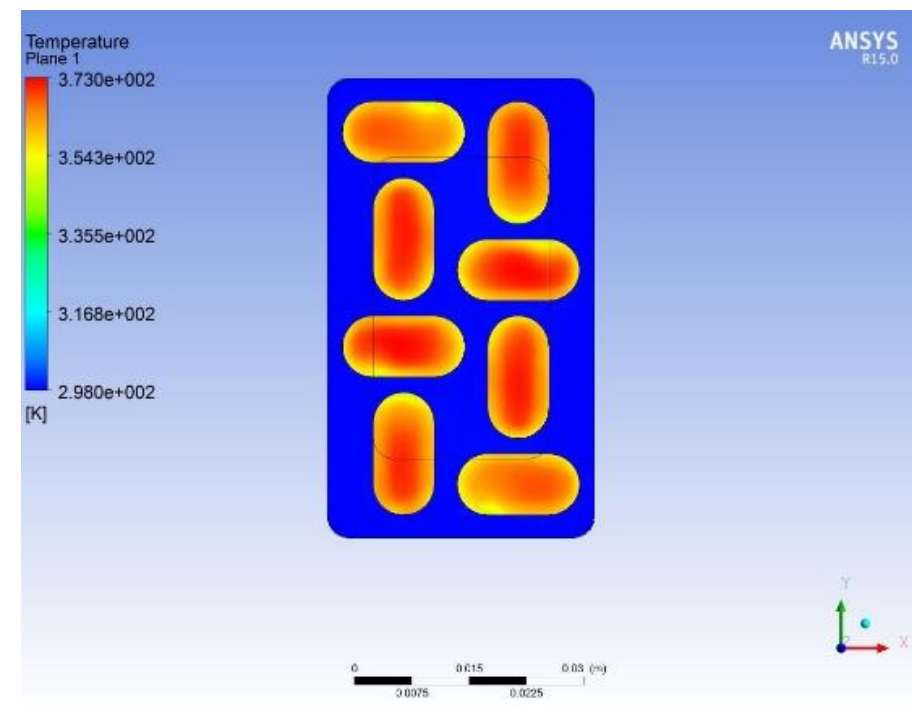

Fig. 10. Ellipsoid $\mathrm{X}=0,06 \mathrm{~m}$ section view

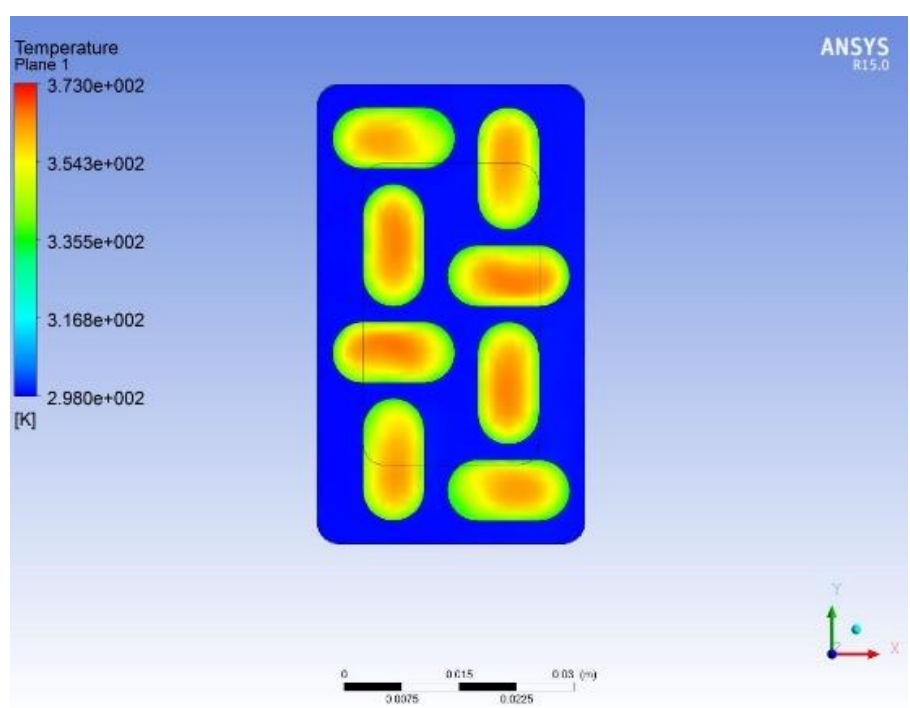

Fig. 11. Ellipsoid $X=0,12 \mathrm{~m}$ section view

The circular tube geometry shown in Figure 6 and the ellipsoid tube geometry shown in Figure 9 are cooled with the help of the refrigerant sent straight through the air ducts, starting from the hot air duct inlets. Since the tube layouts are placed vertically and horizontally in ellipsoidal tube geometry, the refrigerant flowing through the channels circulates cyclically on the tube surfaces (Figure 10 and Figure 11). The results obtained at 0,06 $\mathrm{m} \mathrm{X}$ distance for both designs are shown in Figure 7 and Figure 10. It is seen that the effect area is higher in ellipsoidal sections from the tube surfaces to the inner points. The positive effect of ellipsoidal tube geometry on heat transfer is more evident for $\mathrm{X}=0,12 \mathrm{~m}$ (Figure 8 and Figure 11).

The temperature of the refrigerant was naturally observed to be high in the region of $\mathrm{x}=0-0.06 \mathrm{~m}$, where the air first comes into contact with the refrigerant, and lower in the region of $x=0.06-0.18$. It is seen that the temperature interactions have a more uniform distribution in the circular section system, this distribution is not uniform in the ellipsoid section, the temperature interaction in the ellipsoid section is higher in horizontal tubes, and the temperature distribution in vertical tubes is uniform.

In the study, it was observed that when the velocity of the air at the inlet is kept constant and the velocity of the refrigerant with a temperature of $25 \mathrm{C}$ is increased, the temperature of the outgoing air decreases in both geometries, and there is an increase in the temperature when the velocity of the refrigerant is kept constant and the velocity of the air at the inlet is increased. It is an expected result that the outlet temperature of the fluid decreases as the refrigerant velocity increases, and the fluid outlet temperature increases as the hot fluid velocity increases (Figure 12.), (Figure 13). Depending on the refrigerant and hot fluid velocity, it is seen that the refrigerant and hot fluid outlet temperatures are higher in the circular section than in the ellipsoidal section. It was determined that the intercooler with ellipsoidal cross-section geometry has a temperature drop of nearly $10 \%$ compared to the circular crosssection geometry. 

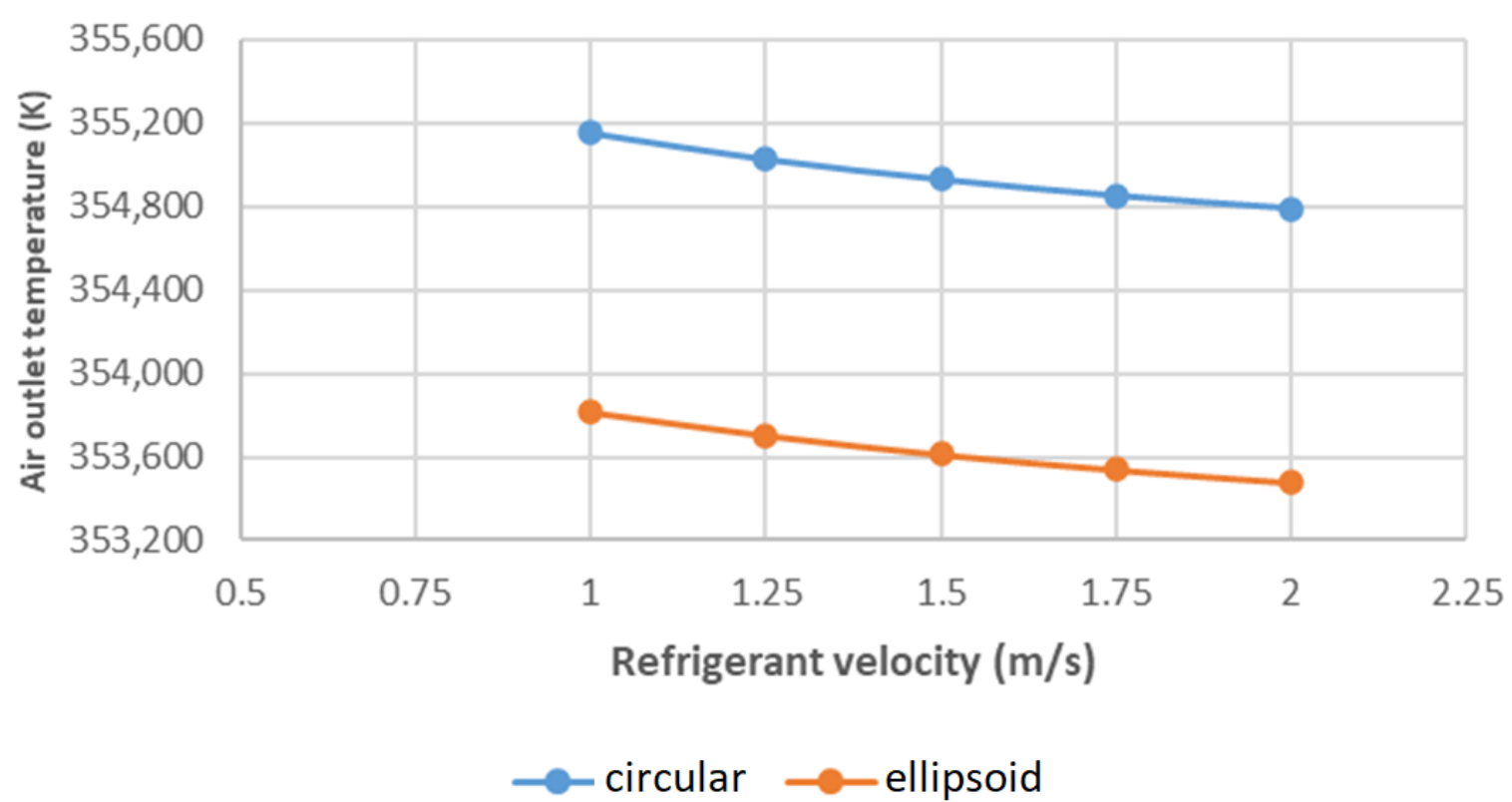

Fig. 12. Refrigerant velocity - Air outlet temperature graph

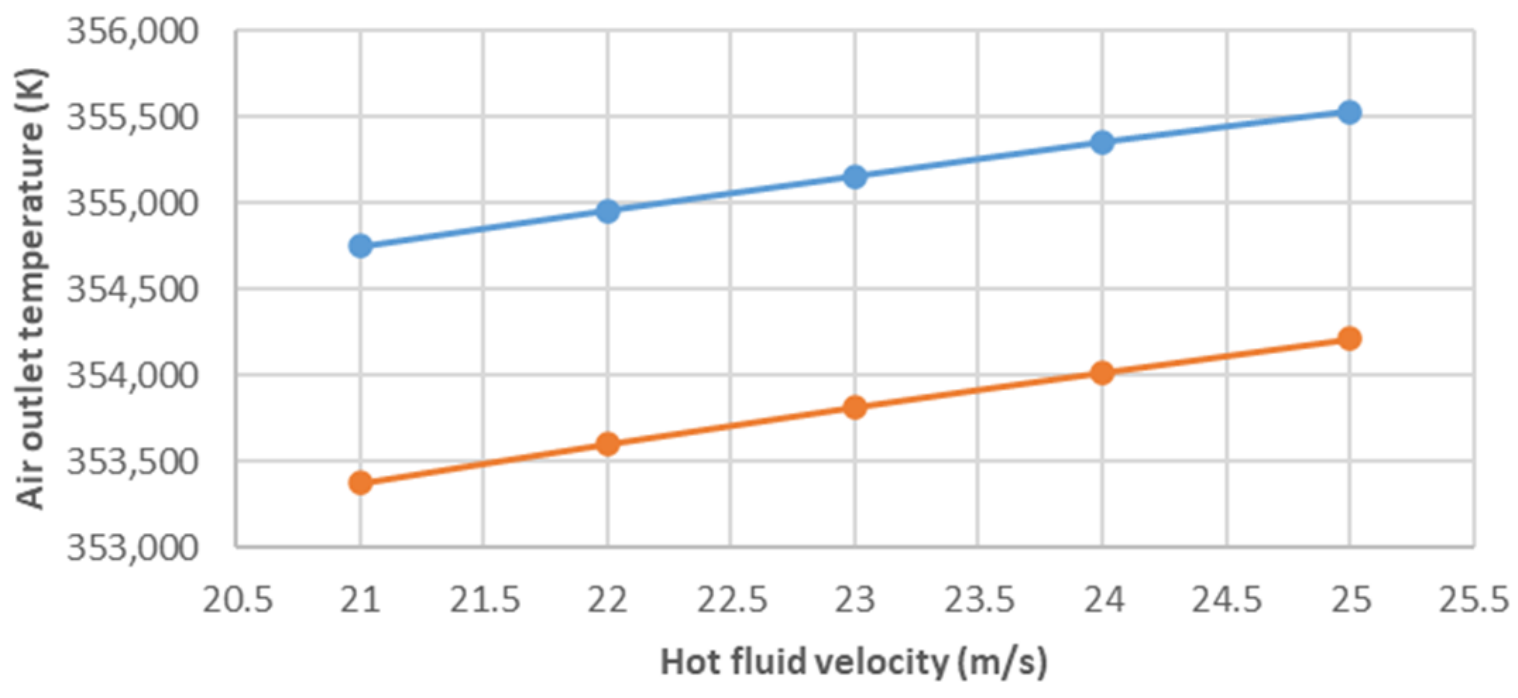

$\multimap$ circular $\rightarrow$ ellipsoid

Fig. 13. Air inlet velocity - Air outlet temperature graph

\section{Conclusion}

In this study, two different intercooler designs were developed in the light of literature studies and theoretical calculations, and they were analyzed with ANSYS Fluent Computational Fluid Dynamics (CFD) software. According to the data obtained:

- Since heat transfer surface distributions are used more effectively in ellipsoidal tube sections, a flow cycle was created, and more cooling was provided approximately $10 \%$ compared to circular tube sections.
- It was understood that the refrigerant velocity has an effect on the heat drawn from the hot ai for both intercooler geometers. By increasing the refrigerant velocity from $1 \mathrm{~m} / \mathrm{s}$ to $2 \mathrm{~m} / \mathrm{s}$, the efficiency of both intercooler geometries increased by approximately $1 \%$.

- The increase in hot air inlet speeds negatively affected the cooling of the compressed air coming out of the compressor for both intercooler inlets. By increasing the hot fluid velocity from $21 \mathrm{~m} / \mathrm{s}$ to $25 \mathrm{~m} / \mathrm{s}$, the efficiency of both intercooler geometries decreased by approximately $1 \%$. 
As stated in the light of the obtained data, since the cooling performance is good in ellipsoidal tube sections, it is predicted that intercoolers with ellipsoidal section tubes can be made smaller in size compared to circular sections and may have positive results in terms of production and operation.

\section{Conflict of Interest Statement}

The authors declare that there is no conflict of interest in the study.

\section{CRediT Author Statement}

Cengiz Öner: Supervision, Conceptualization, Methodology, original draft, Validation, Writing-review\& editing Ali Öz: Writing-review\& editing, visualization

\section{References}

[1] Başaran H. Ü. Utilizing Exhaust Valve Opening Modulation for Fast Warm-up of Exhaust After-treatment Systems on Highway Diesel Vehicles. International Journal of Automotive Science and Technology. 2020; 4(1): 10-22.

[2] Gürbüz H., Ateş D. A numerical study on processes of charge and discharge of latent heat energy storage system using RT27 paraffin wax for exhaust waste heat recovery in a SI engine. International Journal of Automotive Science and Technology. 2020; 4(4): 314-327.

[3] Kula G., Ciniviz M. Atmospheric and Turbocharged Experimental Investigation of Heavy Vehicle Compressor Air Inlet Line. International Journal of Automotive Science and Technology. 2020; 4(4): 213-222.

[4] Öz A. Investigation of the effect of L5Cu compound in diesel fuel on in-cylinder pressure, engine performance and exhaust emissions. International Journal of Oil, Gas and Coal Technology. 2021:28(1):101-114.

[5] Öz A. Experimental evaluation of L5Ni addition to diesel fuel in a turbo diesel engine. Indian Journal Chemical Technology. 2019: 26;158-163.

[6] Gürbüz, H., Akçay, İ.H., Evaluating the effects of boosting intakeair pressure on the performance and environmental-economic indicators in a hydrogen-fueled SI engine, International Journal of Hydrogen Energy, 2021; 46(56): 28801-28810.

[7] Güney B, Öz A. Microstructure and chemical analysis of NOx and particle emissions of diesel engines. International Journal of Automotive Engineering and Technologies. 2020;9(2): 105-112.

[8] Güney B, Öz A. Microstructure and chemical analysis of vehicle brake wear particle emissions. Avrupa Bilim ve Teknoloji Dergisi. 2020:19;633-642.

[9] Mazman M. Gizli Isı Depolaması ve Uygulamaları. Doktora Tezi, Çukurova Üniversitesi, Fen Bil. Ens., Adana, 2006.

[10]Çengel Y, Boles M. Mühendislik Yaklaşımıyla Termodinamik. Güven Bilimsel Kitabevi, 2008, İzmir.

[11]Öztürk H. Isı Depolama Tekniğii. Teknik Yayınevi, 2008, Ankara.

[12]Öztürk HH. Güneş Enerjisinin Gizli Isı Tekniği ile Depolanması. Tesisat Mühendisliği Dergisi. 2005: 100; 16-31. [13]http://biyokure.org/isi-degistirici-cesitleri/7009/ 26.08.2016.

[14]http://www.emo.org.tr/ekler/fe77ac7060e716f_ek.pdf?dergi=298 /17.09.2016.

[15]http://otomobilteknoloji.blogspot.com.tr/2016/06/turbo-nedirturbo-sarj-sistemi-calisma-prensibi.html/10.09.2016.

[16]http://www.motorsanas.com/tr/turbosarjnedir.html/11.09.2016.

[17]Canlı E. İçten Yanmalı Motorlarda Aşırı Doldurma ve Ara Soğutma Sistemleri, Yüksek Lisans Tezi, Fen Bilimleri Enstitüsü, Selçuk Üniversitesi, 2010.

[18]Muqeem M. Turbocharging with Air Conditioner Assisted Intercooler. IOSR Journal of Mechanical and Civil Engineering. 2012:2(3);38-44.

[19]Dağlar S. Ağır Vasıta Araç Motorları için Tek Kademeli Değişken Geometrili ve Çift Kademeli Turbo şarj Karşılaştırması ve Seçimi. Yüksek Lisans Tezi. İstanbul Teknik Üniversitesi, Fen Bilimleri Enstitüsü, 2012.

[20]Özülkü M. Aşırı Doldurmalı Dizel Bir Motorda Ara Soğutmanın (Aftercoolıng) Motor Performansı ve Egzoz Emisyonlarına Etkisinin Deneysel Analizi. Yüksek Lisans Tezi İstanbul Teknik Üniversitesi, Fen Bilimleri Enstitüsü, 2002.

[21]Zhang Q, Qin S, Ma R. Simulation and experimental investigation of the wavy fin-and-tube intercooler, Case Studies in Thermal Engineering. 2016; 8:32-40.

[22]Dwivedi VD, Rai R. Modeling and Fluid Flow Analysis of Wavy Fin Based Automotive Radiator. Int. Journal of Engineering Research and Applications. 2015;5(1):17-26.

[23]Wais P. Influence of Fin Thickness and Winglet Orientation on Mass and Thermal Efficiency of Cross-Flow Heat Exchanger. Applied Thermal Engineering. 2016; 102:184-195.

[24]Mifdal MYA, Nuraida MH, Norzalina O, Shamil AH. Turbo Intercooler Cooling System. International Journal of Engineering Science Invention. 2015:2319 - 6726.

[25]Lajqi NB, Baxhaku BI, Lajqi SB. Effect of Intercooler on Turbocharged Diesel Engine Performance. 13th International Research/Expert Conference, Hammamet, October 2009, Tunisia. 